\title{
The effect of temperature on the strength of two different granites
}

\author{
Anita Török, Ákos Török* \\ Department of Engineering Geology and Geotechnics, Budapest University of Technology and \\ Economics, Budapest, Hungary
}

Received: January 15, 2014; accepted: May 9, 2016

The paper provides information on the mechanical properties of granitic rocks that were subjected to heat. Two types of granitic rocks were tested under laboratory conditions at temperatures of $23{ }^{\circ} \mathrm{C}$, $300{ }^{\circ} \mathrm{C}$ and $600{ }^{\circ} \mathrm{C}$. The granitic rock from Bátaapáti (Mórágy Granite) is a pinkish leucocratic monzogranitic type while the second type is grey granite from Mauthausen (Austria). The samples were placed in furnace and temperature raised to $300^{\circ} \mathrm{C}$. Other set of samples were heated to $600{ }^{\circ} \mathrm{C}$. Mechanical tests were performed on non-heated and heated samples and the test results were compared. Heating to $300{ }^{\circ} \mathrm{C}$ caused a slight increase in the uniaxial compressive strength and in indirect tensile strength, with reference to the samples kept at $23{ }^{\circ} \mathrm{C}$. A drastic drop in both values was observed when samples were heated to $600{ }^{\circ} \mathrm{C}$. The density of the samples did not show a major change up to $300^{\circ} \mathrm{C}$. On the contrary, a decrease in ultrasonic pulse velocity was observed, with an additional significant loss when samples subjected to $600{ }^{\circ} \mathrm{C}$ were compared to the reference samples of $23^{\circ} \mathrm{C}$. This decrease can be related to the initiation of micro-cracks. With increasing temperature the Young modulus of both granites was reduced.

Keywords: Mórágy Granite, Mauthausen Granite, petrophysical properties, thermal behavior

*Corresponding author: Ákos Török, Müegyetem rkp. 1, K/10, H-1111 Budapest, Hungary

E-mail: torokakos@mail.bme.hu 


\section{Introduction}

High temperature causes irreversible changes in the properties of rocks. These include thermal cracking, changing of color and also a loss in strength or complete disintegration of the fabric (Heuze 1983). In case of fire it often leads to the collapse of buildings (Russo and Sciarretta 2013) or endangers tunnels. In the last decade fires in tunnels have been generating greater hazards for the rocks in their natural environment. In such an emergency, fire and smoke together are dangerous for human life; tunnel walls, made mainly from reinforced concrete, collapse and the host rocks have also been altered. Other cases are when temperature rises are related to radionuclide breakdown processes and the heat they generate. The thermal effect can be felt over several centuries and several hundred meters away (Hodgkinson and Bourke 1980). Rising temperature has a large influence on the long-term stability of underground radioactive waste storage locations. Young's modulus, compressive strength and tensile strength values decrease significantly when heat increases (Török et al. 2013), meaning that all petrophysical properties are deteriorating. These petrophysical properties depend not only on the temperature regime but also on the texture and the mineral composition of the rock. High temperature causes the generation of new micro-cracks and the opening up of existing ones. This phenomenon significantly influences the strength of the rocks. Low- and medium-level radioactive waste - stored in Hungary in Bátaapáti at the National Radioactive Waste Repository (Gyalog et al. 2010) - will not experience fire-related very high temperatures but could be exposed to lower temperature. The present research focuses on the petrophysical properties of granitic rocks that are exposed to high temperatures, dealing with two granitic rocks, one of Bátaapáti and the other from Austria (Mauthausen). The specimens were heated under laboratory conditions; physical properties such as density, ultrasonic pulse velocity, tensile strength and uniaxial compressive strength data were recorded. The results were evaluated and compared to the dataset of previous publications such as Heuze (1983) and Dwivedi et al. (2008).

\section{Materials}

The study relies on two different granitic rocks. The first one is from the Hungarian location of Bátaapáti, where the country operates the National Radioactive Waste Repository (Fig. 1). A larger area in the Mórágy region is formed by massive granitic-monzogranitic rock bodies (Balla et al. 2009; Gyalog et al. 2010). The tested granite from the Bátaapáti region did not belong to the most typical "Mórágy Granite" type; it is from the close vicinity of the deformed clay-bearing Patrik Fault Zone. It has a pinkish color and contains abundant leucocratic minerals (Fig. 2). This highly deformed zone is characterized by a variety of granitic and clay-bearing rocks (Maros et al. 2010). The samples were collected from the border zone between the dam- 


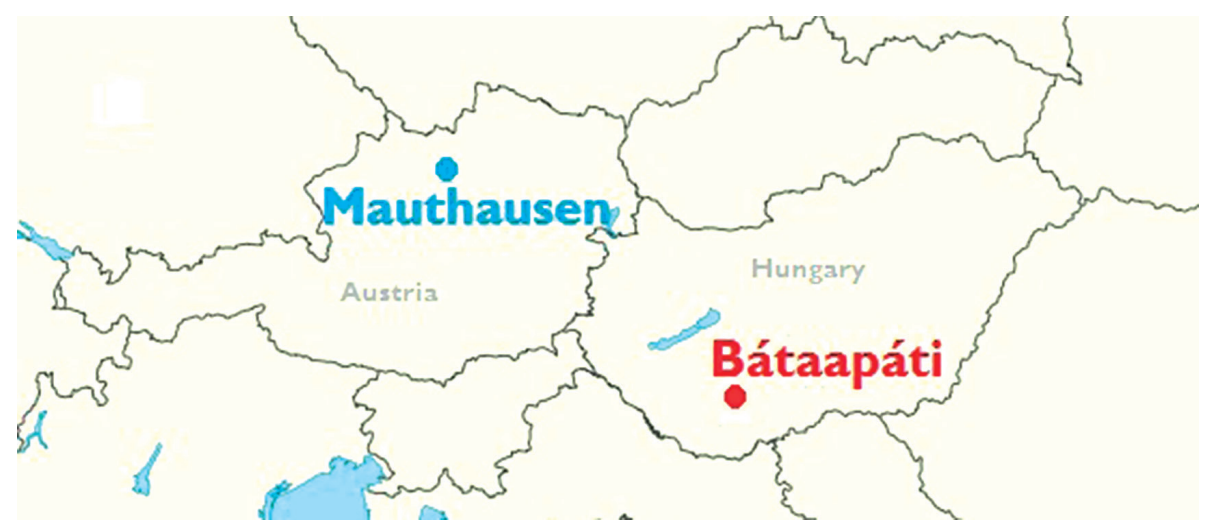

Fig. 1

Location of Bátaapáti in South Hungary and Mauthausen in Upper Austria

aged zone and the core zone of the structure. The material from the fault zone has a lower load-bearing capacity in terms of tunneling, i.e. this rock may be critical in terms of the tunnel stability of the Radioactive Waste Repository. Two pinkish-colored and one fine-grained granite blocks were available from the site, henceforth referred to in this paper as "Patrik Granite". The latter is characterized by abundant quartz and K-feldspars. This lithotype is considered as a leucocratic monzogranitic rock. The mineralogical composition and main characteristics are described in detail by Balla et al. (2009), Gyalog et al. (2010) and Maros et al. (2010).

The second, grey-colored granite is from the Upper Austrian Mauthausen (Fig. 1). From that type of granite seven blocks were used and cylindrical samples were drilled from those blocks. Blocks numbered from 1 to 5 contained finer crystalline, while blocks numbered 6 to 7 were coarse-crystalline granites (Fig. 2). The main minerals present in this granite are quartz, white K-feldspar, zoned plagioclase, quartz and dark mica. The geochemical composition and detailed mineralogical description of these Variscan granites were provided in detail (Breiter 2010).

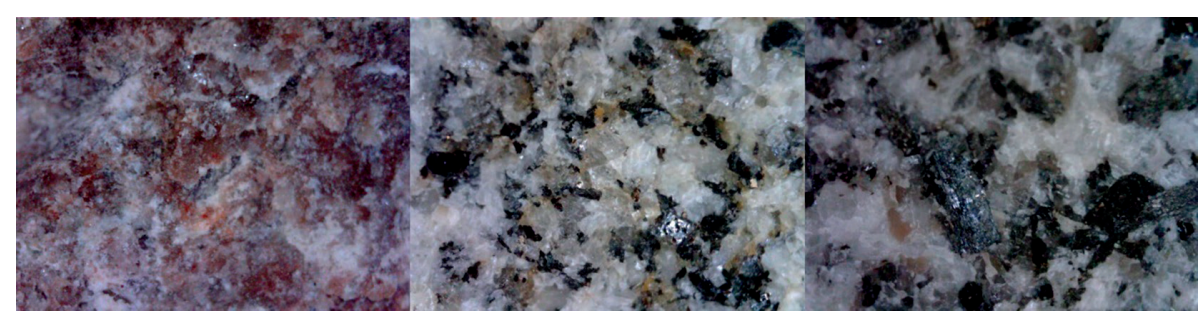

Fig. 2

Close-up view of Patrik Granite (left), the fine and the coarse-grained Mauthausen granite (middle and right). Field of view is $3 \mathrm{~cm} * 2 \mathrm{~cm}$ for all samples 
In this study, these granites were exposed to high temperatures. The typical minerals of the granites are quartz, K-feldspar, plagioclase, biotite and amphibole. The test temperature was chosen bearing in mind the temperature $\left(573{ }^{\circ} \mathrm{C}\right)$ at which $\alpha$-quartz is transformed into $\beta$-quartz.

\section{Methodology}

From the available blocks of "Patrik Granite", cylindrical samples of different diameters $(3.6 \mathrm{~cm}$ and $4.8 \mathrm{~cm}$, respectively) were taken. The samples had either a 2:1 or a 1:1, height:diameter ratio. From the Mauthausen Granite samples of $4.8 \mathrm{~cm}$ in diameter were drilled and later cut to cylindrical shape at the 2:1 and 1:1, height:diameter ratio.

For each of the samples the dimensions and weight were measured. The non-destructive test also included the recording of ultrasound pulse velocity prior to and after the heat tests. Uniaxial compressive strength and indirect tensile strength tests were performed from the destructive tests on the cylindrical samples. The names and the numbers of applied standardized tests are given in Table 1.

Table 1

Test methods and standards

\begin{tabular}{lll} 
Test & No. of standard & Name of the standard/methods \\
\hline $\begin{array}{l}\text { Determination of } \\
\text { ultrasonic pulse velocity }\end{array}$ & EN 14579:2005 & $\begin{array}{l}\text { Natural stone test methods. Determination of sound } \\
\text { speed propagation. }\end{array}$ \\
\hline Rock quality index & MSZ 18282/4-1978 & Sampling and analyses of natural stone. \\
\hline $\begin{array}{l}\text { Heat shock } \\
\text { EN 14066:2003 }\end{array}$ & $\begin{array}{l}\text { Natural stone test methods. Determination of } \\
\text { resistance to ageing by thermal shock }\end{array}$ \\
\hline $\begin{array}{l}\text { Uniaxial compressive } \\
\text { strength }\end{array}$ & EN 1926:2007 & $\begin{array}{l}\text { Natural stone test methods. Determination of uniaxial } \\
\text { compressive strength. }\end{array}$ \\
\hline $\begin{array}{l}\text { Indirect tensile strength } \\
\text { EN 18285-2:1979 }\end{array}$ & $\begin{array}{l}\text { Test methods of natural stone samples. Indirect tensile } \\
\text { strength. }\end{array}$ \\
\hline
\end{tabular}

The tests were carried out under four conditions: air-dry $\left(23^{\circ} \mathrm{C}\right)$, water-saturated condition, and after heat shock of $300^{\circ} \mathrm{C}$ and $600^{\circ} \mathrm{C}$, respectively. To obtain the proper temperature regime, a furnace was used in which the temperature was held at $300{ }^{\circ} \mathrm{C}$ and $600{ }^{\circ} \mathrm{C}$ for six hours. After the heat shock the samples were cooled down to reach room temperature. Water saturation tests were made according to EN 13755:2001. 


\section{Results and interpretation}

\section{Bulk density}

The bulk densities of the two studied rocks are very similar to each other. The bulk density of the Patrik Granite is $2.58 \mathrm{~g} / \mathrm{cm}^{3}$ and that of the Mauthausen Granite is 2.68 $\mathrm{g} / \mathrm{cm}^{3}$ in air dry condition. The changes in bulk density under different test conditions are low compared to the original air-dry value (Fig. 3). A tendency can be observed that in air dry state the Mauthausen Granite has a $4 \%$ higher bulk density than that of the Patrik Granite. With increasing temperature the bulk density is slightly reduced: the bulk density of the grey Mauthausen Granite reached its minimum at $300{ }^{\circ} \mathrm{C}$, while that of the pinkish Patrik Granite at $600^{\circ} \mathrm{C}$. This represents a decrease of $3.5 \%$ for the Mauthausen granite and $1.5 \%$ for the Patrik Granite.

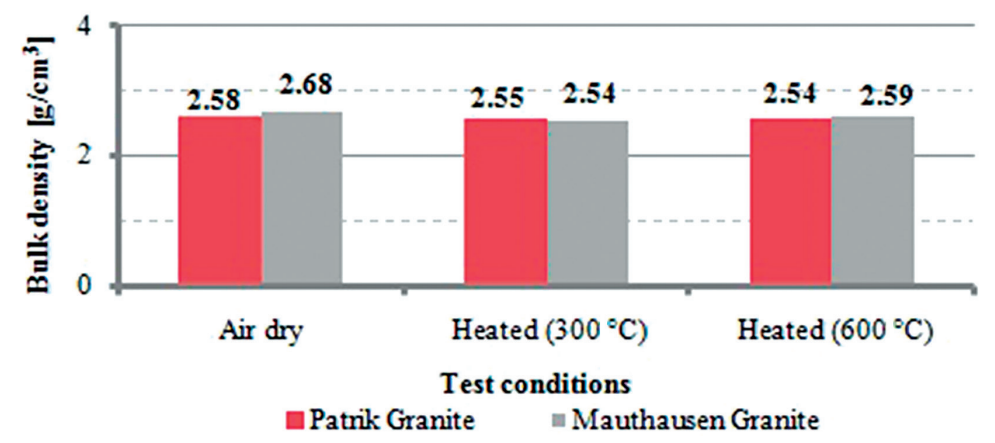

Fig. 3

Bulk densities of granites in three test conditions

After water saturation the bulk density of the pinkish Patrik Granite shows a slight increase (1\%), while that of the grey rock did not change.

\section{Effective porosity}

The mechanical properties of the rocks are significantly influenced by the open porosity of the samples. The average effective porosity of the pinkish granite is three times greater than that of the gray granite (Fig. 4). In case of the pink granite, not only is the porosity greater, but also its standard deviation is higher (1.09). The standard deviation of the Mauthausen Granite is very low, it is only 0.15 .

The open porosity of the two studied granites is nearly the same, and is less than $5 \%$. According to Gálos and Vásárhelyi (2006), the strength mainly depends on the effective porosity of a given lithotype. The rock classification is based on changes in properties; changes according to the variable $(\lambda)$ are given in Table 2. 


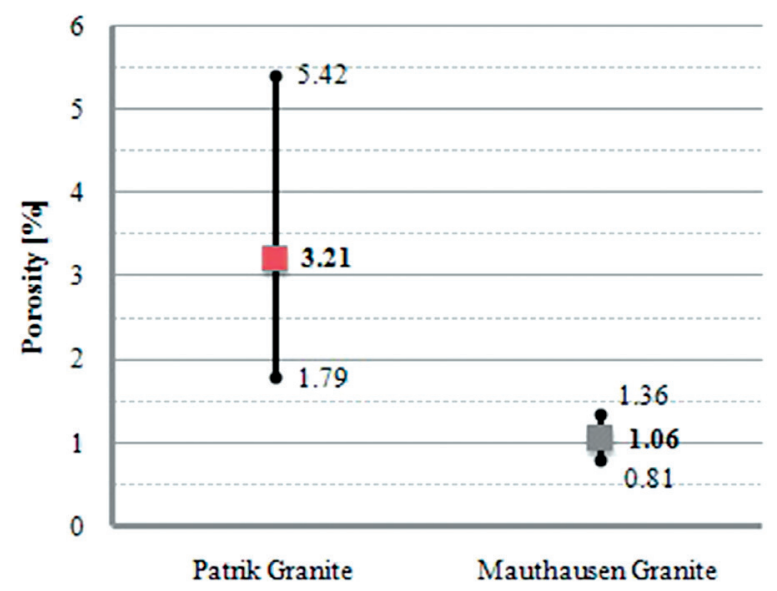

Fig. 4

Porosities of granites (mean values are marked by small rectangles)

The factor of change of the Patrik Granite is 0.72 ; therefore it is very sensitive to water, while the Mauthausen Granite is less prone to water-related changes (its factor of change is 0.89 ; Table 2). Overall, the strength of the pink granite decreases more when it is water-saturated, than that of the gray Mauthausen granite.

Table 2

Changes in the strength by water, calculated $(\lambda)$ - factor of change

\begin{tabular}{ll}
\hline$\lambda$ & Rating \\
\hline $0.0-0.5$ & Very poor \\
\hline $0.5-0.75$ & Poor \\
\hline $0.75-0.9$ & Moderately good \\
\hline $0.9-1.0$ & Good \\
\hline
\end{tabular}

Patrik Granite $(0.72)$ - poor

Mauthausen Granite (0.89) - moderately good

\section{Ultrasonic pulse velocity}

The granite from the Patrik Fault Zone has a lower bulk density than the Mauthausen Granite. This observation was confirmed by the ultrasonic pulse velocity tests (Fig. 5). The average values of ultrasonic pulse velocity of the two rocks were different. The average bulk density of the pinkish granite was $2.58 \mathrm{~g} / \mathrm{cm}^{3}$ which cor- 


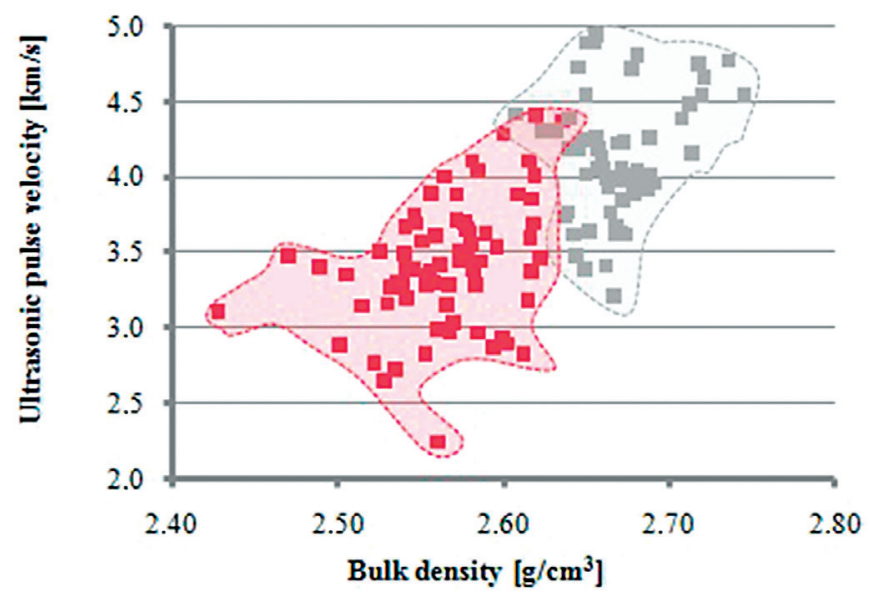

- Patrik Granite $\quad$ Mauthausen Granite

Fig. 5

The ultrasonic pulse velocity as a function of bulk density

responds to an ultrasonic pulse velocity of $3.43 \mathrm{~km} / \mathrm{s}$. On the other hand, samples of the grey granite had an average bulk density of $2.68 \mathrm{~g} / \mathrm{cm}^{3}$. The ultrasonic pulse velocity was $4.13 \mathrm{~km} / \mathrm{s}$ which is $20 \%$ higher than that of the pink granite. The lower ultrasonic pulse velocity in the Patrik Granite can be explained by the higher porosity of the rock, since its open porosity is three times greater than that of the Mauthausen Granite. The standard deviations of the ultrasonic pulse velocity values were the same (0.40).

The ultrasonic pulse velocity depends on the condition of the sample (Fig. 6). A clear trend was observed: with increasing temperature the ultrasonic pulse veloc-

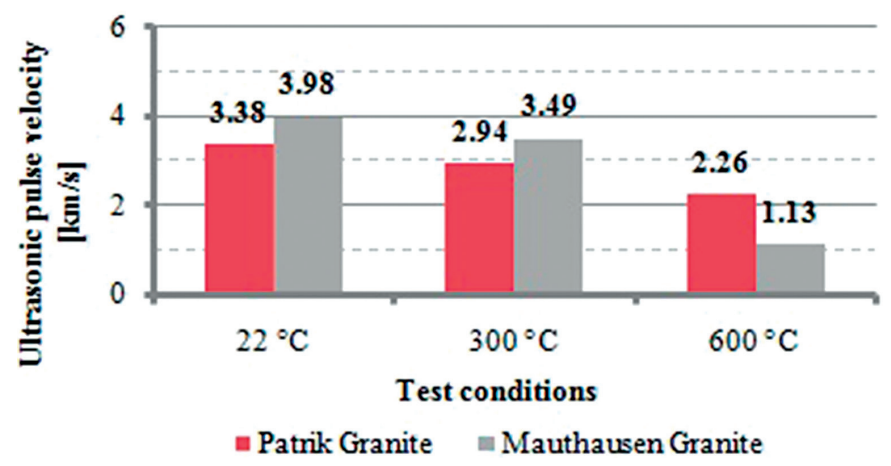

Fig. 6

The ultrasonic pulse velocity as a function of the test conditions 
ity decreases strongly. The samples which experienced $600{ }^{\circ} \mathrm{C}$ of heat shock had a reduced ultrasonic pulse velocity, which represent a loss of $72 \%$ (Mauthausen Granite) and of 33\% (Patrik Granite) compared to the original air-dry ultrasonic pulse velocities.

The effect of high temperature on the bulk density is negligible, while the ultrasonic pulse velocity is drastically reduced. This suggests that the minerals in the rock were transformed with increasing temperature. Of the rock-forming minerals quartz is one that has a known transformation at $573{ }^{\circ} \mathrm{C}$. At $300{ }^{\circ} \mathrm{C}$ only a $12 \%$ reduction in the ultrasonic pulse velocity was measured. It was further abruptly decreased at 600 ${ }^{\circ} \mathrm{C}$. The differences in changes of bulk densities due to increasing temperature can be explained by the different mineralogical composition and micro-fabric of the two studied granites.

\section{Uniaxial compressive strength}

The uniaxial compressive strength test was carried out on 2:1 (height:diameter) cylindrical samples. The results of the uniaxial compressive strength tests (axial displacement - measured compressive strength) are shown in Fig. 7.

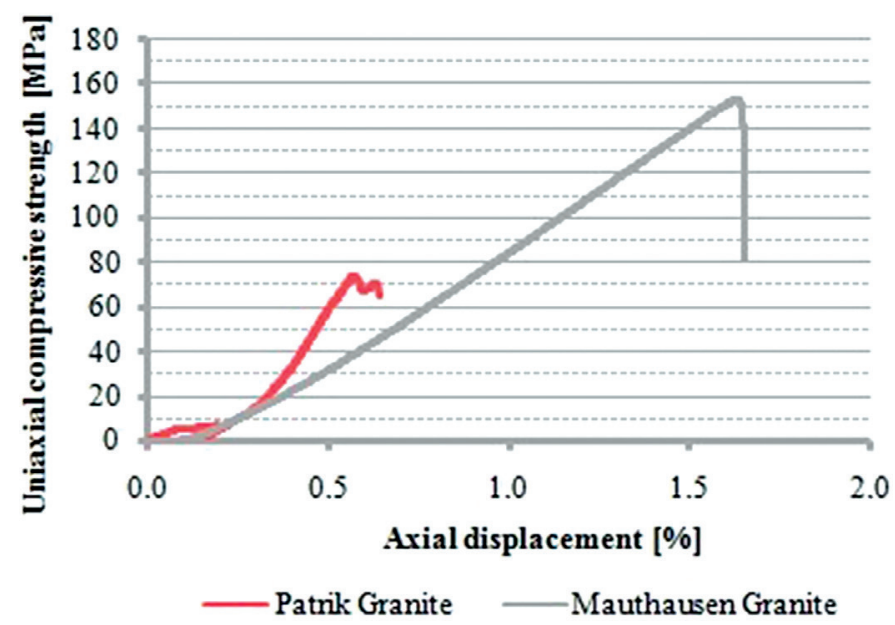

Fig. 7

Axial displacement - compressive strength diagram

Cylindrical samples of the Patrik Granite with two different diameters $(3.6 \mathrm{~cm}$ and $4.8 \mathrm{~cm}$ ) were tested. It was observed that samples of different diameter had different compressive strength (Table 3). The larger samples had lower compressive strength values - probably because the larger samples had a larger number of dis- 
continuities (micro-cracks) and the inhomogeneity was better detected. Hoek and Brown proposed an empirical correlation for correcting the size-effect (Gálos and Vásárhelyi 2006):

$\sigma_{c 50}=\frac{\sigma_{c}}{\left(\frac{50}{d}\right)^{0.18}}$

where:

$\sigma_{c 50}$ is the compressive strength of a $50 \mathrm{~mm}$ diameter specimen

$\sigma_{c} \quad$ is the measured compressive strength

$d \quad$ is the diameter of the specimen

Table 3

Compressive strength of samples of different diameter of the Patrik Granite and the dependence of strength on sample diameter

\begin{tabular}{|c|c|c|c|c|c|c|}
\hline & \multicolumn{2}{|c|}{ Specimen type } & $\begin{array}{l}\text { Uniaxial } \\
\text { compressive } \\
\text { strength [MPa] } \\
(2: 1 \text { height: } \\
\text { diameter ratio, } \\
\text { diameter } \\
\text { of } 50 \mathrm{~mm})\end{array}$ & $\begin{array}{l}\text { Maximum } \\
\text { of the uniaxial } \\
\text { compressive } \\
\text { strength } \\
\text { [MPa] }\end{array}$ & $\begin{array}{l}\text { Minimum } \\
\text { of the uniaxial } \\
\text { compressive } \\
\text { strength } \\
\text { [MPa] }\end{array}$ & $\begin{array}{l}\text { Standard } \\
\text { deviation } \\
\text { of the uniaxial } \\
\text { compressive } \\
\text { strength }\end{array}$ \\
\hline \multirow{4}{*}{ 弟泀 } & \multirow{3}{*}{$\begin{array}{l}3.6 \mathrm{~cm} \\
\text { diameter }\end{array}$} & Air-dry & 54.07 & 74.3 & 39.1 & 15.3 \\
\hline & & Heated $\left(300^{\circ} \mathrm{C}\right)$ & 91.36 & 96.9 & 86.8 & 3.8 \\
\hline & & Heated $\left(600^{\circ} \mathrm{C}\right)$ & 42.86 & 42.9 & 75.6 & 13.2 \\
\hline & $\begin{array}{l}4.8 \mathrm{~cm} \\
\text { diameter }\end{array}$ & Air-dry & 44.30 & 62.6 & 23.4 & 16.1 \\
\hline \multirow{3}{*}{ 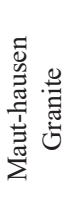 } & \multirow{3}{*}{$\begin{array}{l}4.8 \mathrm{~cm} \\
\text { diameter }\end{array}$} & Air-dry & 159.40 & 182.60 & 138.07 & 14.30 \\
\hline & & Heated $\left(300^{\circ} \mathrm{C}\right)$ & 158.67 & 194.39 & 83.77 & 36.85 \\
\hline & & Heated $\left(600^{\circ} \mathrm{C}\right)$ & 111.79 & 157.06 & 66.18 & 29.84 \\
\hline
\end{tabular}

The two different granite samples have very different uniaxial compressive strength (UCS) values. The grey granite (Mauthausen Granite) has an average UCS value of $159.40 \mathrm{MPa}$, while the pink granite (Patrik Granite) has a mean compressive strength of $50.41 \mathrm{MPa}$ in air-dry condition. 
With increasing temperature up to $300{ }^{\circ} \mathrm{C}$ the uniaxial compressive strength of Patrik Granite increased by $81 \%$ (Fig. 8). On the other hand, at $600{ }^{\circ} \mathrm{C}$ the compressive strength decreased by $15 \%$. In contrast to this, the Mauthausen Granite did not show any increase in compressive strength with increasing temperature, and above $300{ }^{\circ} \mathrm{C}\left(\right.$ at $\left.600{ }^{\circ} \mathrm{C}\right)$ it showed a loss of $30 \%$ in strength.

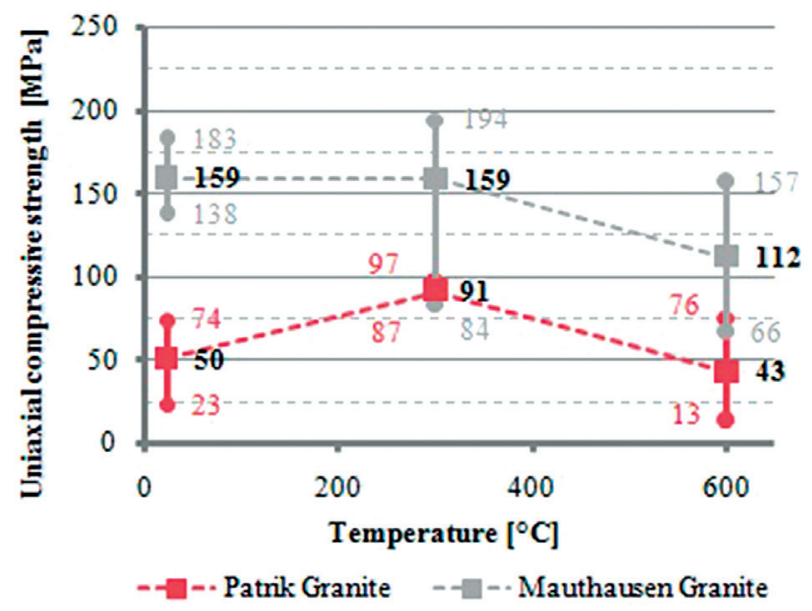

Fig. 8

Compressive strength of granites as a function of temperature

The uniaxial compressive strength of the Patrik Granite increases until the temperature reaches $300{ }^{\circ} \mathrm{C}$, whereas that of the Mauthausen Granite remains unchanged. Decreasing compressive strength at $600{ }^{\circ} \mathrm{C}$ is the common feature of these granites, which is half the rate for the pink granite. These two types of granite behave differently due to the temperature increase, the fundamental reason for which is the differences in composition. Accurate analysis of the impact of individual minerals is still pending.

Increasing compressive strength is a typical feature of Indian granites. Dwivedi et al. (2008) reported that at $100{ }^{\circ} \mathrm{C} \mathrm{a} 4 \%$ increase, and at $160{ }^{\circ} \mathrm{C} \mathrm{a} 13 \%$ increase, were measured as compared to samples at $30{ }^{\circ} \mathrm{C}$.

In the case of the pink granite, the ultrasonic pulse velocity was $20 \%$ lower than in the grey granite. This is in accordance with the compressive strength observations.

\section{Young's modulus}

Young's modulus was determined during the compressive strength test by measuring the axial deformation; therefore it was determined in each test condition. According to the Dwivedi et al. (2008) Young's modulus shows variable trend until it 
reaches a peak at $300{ }^{\circ} \mathrm{C}$; at higher temperatures it starts to decrease strongly. Similar facts were presented by Heuze (1983). Up to $300^{\circ} \mathrm{C}$ the measured samples show a decreasing Young's modulus, and above that temperature, at $600{ }^{\circ} \mathrm{C}$, the values dropped dramatically. The Patrik Granite shows a loss in Young's modulus of $10 \%$, while that of the Mauthausen Granite is only $5 \%$ at $300{ }^{\circ} \mathrm{C}$ (Fig. 9). With increased temperature Young's modulus' values decrease; the pink granite experienced a loss of $66 \%$, while the grey granite had values $43 \%$ smaller compared to the air-dry values.

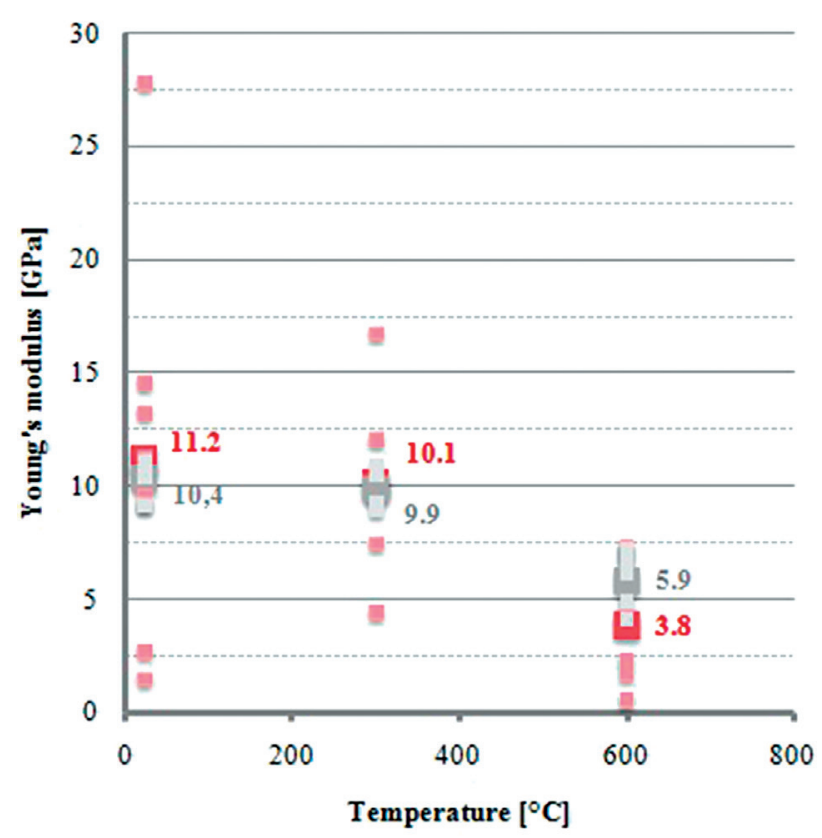

Patrik Granite $\quad$ Mauthausen Granite

Fig. 9

Changes in Young's modulus as a function of temperature

\section{Indirect tensile strength}

The indirect tensile strength tests were carried out on the 1:1, height:diameter scale samples. The tensile strength of the Patrik Granite increased in the initial stage, rising by $9 \%$ at $300{ }^{\circ} \mathrm{C}$ compared to the samples kept at room temperature (Fig. 10). In contrast, the strength of the Mauthausen Granite remained unchanged. A common feature of the two granites is the dramatic decrease in tensile strength at $600{ }^{\circ} \mathrm{C}$. This decrease, in the case of the Mauthausen granite, was $65 \%$, while the pink granite of Bátaapáti lost $56 \%$ of its strength. This means that the strength of the two granites 
became almost equal at $600{ }^{\circ} \mathrm{C}$. The sample size also influenced the tensile strength (Table 4).

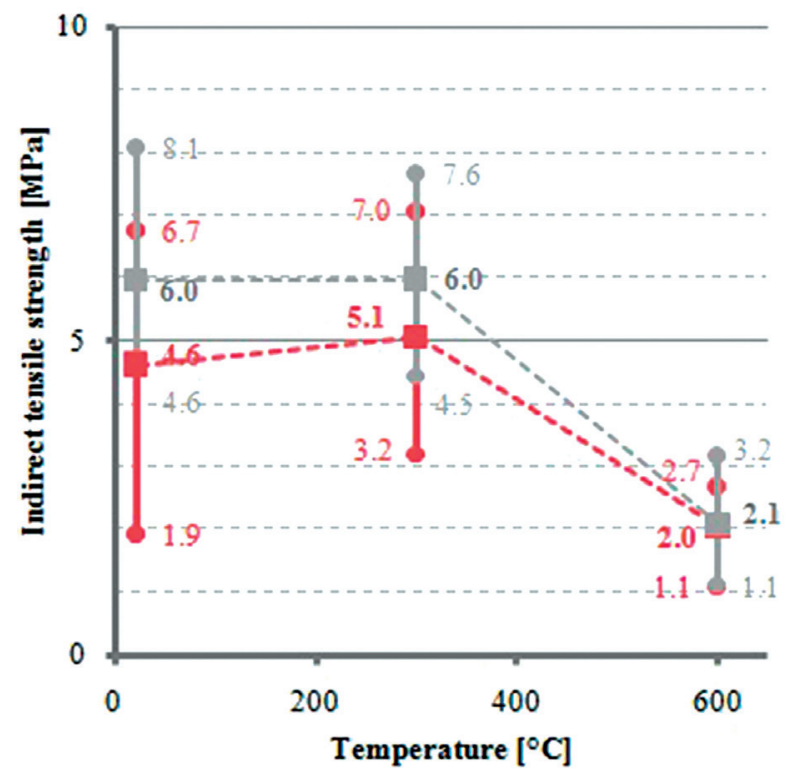

--1-- Patrik Granite --1-- Mauthausen Granite

Fig. 10

Changes in indirect tensile strength as a function of temperature

Table 4

Indirect tensile strength of the studied granites

\begin{tabular}{|c|c|c|c|}
\hline & Specimen type & & Indirect tensile strength [MPa] \\
\hline \multirow{4}{*}{ 弟䓌 } & \multirow{3}{*}{$4.8 \mathrm{~cm}$ diameter } & Air-dry & 4.08 \\
\hline & & Heated $\left(300^{\circ} \mathrm{C}\right)$ & 5.05 \\
\hline & & Heated $\left(600^{\circ} \mathrm{C}\right)$ & 2.05 \\
\hline & $3.6 \mathrm{~cm}$ diameter & Air-dry & 5.19 \\
\hline \multirow{3}{*}{ 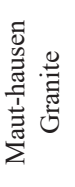 } & \multirow{3}{*}{$4.8 \mathrm{~cm}$ diameter } & Air-dry & 5.97 \\
\hline & & Heated $\left(300^{\circ} \mathrm{C}\right)$ & 5.99 \\
\hline & & Heated $\left(600^{\circ} \mathrm{C}\right)$ & 2.09 \\
\hline
\end{tabular}




\section{Conclusions}

The results of the laboratory tests show the influence of heat on the mechanical properties of the studied granites. The smallest change was observed when the bulk densities of air-dry and heated samples were compared. The ultrasonic pulse velocity tests suggest that at higher temperature, micro-cracks form and ultrasonic velocities become much lower. This suggests that heat changes the microfabric of the rock by generating micro-cracks, but does not significantly influence the bulk density.

The uniaxial strength and indirect tensile strength of the studied granites behave differently with rising temperature. Strength values of the Patrik Granite are essentially characterized by an increase in the initial stage $\left(\sim 300{ }^{\circ} \mathrm{C}\right)$. In contrast, the strength values of the Mauthausen Granite do not show major change in the initial stages of heating (up to $300{ }^{\circ} \mathrm{C}$ ). Above $300{ }^{\circ} \mathrm{C}$ (at $600{ }^{\circ} \mathrm{C}$ ) both tested granites have less strength but the strength reduction is different. The Young's modulus of the granites has the same trend, characterized by slight decrease up to $300{ }^{\circ} \mathrm{C}$ and dramatic loss at $600{ }^{\circ} \mathrm{C}$. The different behavior of the two studied rocks can be explained by the mineralogical composition and micro-fabric differences. Additional studies are required to understand the role of mineralogy and textural characters in the behavior of granites at higher temperatures. An additional further loss in strength is forecast above $600{ }^{\circ} \mathrm{C}$.

\section{Acknowledgements}

We are grateful to the workers of the BUTE, Department of Construction Materials and Engineering Geology, especially to Gyula Emszt, Bálint Pálinkás for the help in the tests, and to Éva Majoros-Lublóy for the advice on the furnace tests. The help of Xénia Hajdu, Ágnes Krupa and Alina Vattai is also appreciated. The financial support of National Research, Development and Innovation (NKFI) Fund (ref. no. $\mathrm{K} 116532)$ is appreciated.

\section{References}

Balla, Z., G. Császár, Z. Gulácsi, L. Gyalog, M. Kaiser, E. Király, L. Koloszár, B. Koroknai, Á. Magyari, Gy. Maros, I. Marsi, P. Molnár, Á. Rotárn-Szalkai, Gy. Tóth 2009: A Mórágyi-rög északkeleti részének földtana. Magyarázó a Mórágyi-rög ÉK-i részének földtani térképsorozatához; 1:10 000 (Geology of the north-eastern part of the Mórágy Block. Explanatory notes to the geological mapseries of the north-eastern part of the Mórágy Block; 1:10,000). - Geological Institute of Hungary, Budapest, 216 p. (in Hungarian)

Breiter, K. 2010: Geochemical classification of Variscan Granitoids in the Moldanubicum (Czech Republic, Austria). - Abh. Geologischen Bundesanstalt, Austria, 65, pp. 19-25.

Dwivedi, R.D., R.K. Goel, V.V.R. Prasad, A. Sinha 2008: Thermo-mechanical properties of Indian and other granites. - International Journal of Rock Mechanics and Mining Sciences, 45/3, pp. 303-315. 
Gálos, M., B. Vásárhelyi 2006: Kőzettestek osztályozása az építőmérnöki gyakorlatban (Classsification of rock bodies in civil engineering practice). - Müegyetemi Kiadó, Budapest, 144 p. (in Hungarian)

Gyalog, L., J. Füri, J. Borsody, Gy. Maros, Sz. Pásztor 2010: Geological mapping of the Bátaapáti tunnels. - Ann. Rep. Geol. Inst. Hung., 2009, pp. 305-322.

Heuze, F.E. 1983: High-temperature mechanical, physical and thermal properties of granitic rocks, a review. - International Journal of Rock Mechanics and Mining Sciences \& Geomechanics, 20/1, pp. $3-10$.

Hodgkinson, D.P., P.J. Bourke 1980: Initial assessment of the thermal stresses around a radioactive waste depository in hard rock. - Annals of Nuclear Energy, 7/10, pp. 541-552.

Maros, Gy., B. Koroknai, K. Palotás, B. Musitz, J. Füri, J. Borsody, P. Kovács-Pálfy, P. Kónya, I. Viczián, K Balogh, Z. Pécskay 2010: Brittle fault zones in the Mórágy Granite (South Transdanubia): New structural and K-Ar data. - Ann. Rep. Geol. Inst. Hung., 2009, pp. 91-112.

Russo, S., F. Sciarretta 2013: Masonry exposed to high temperatures: mechanical behaviour and properties, an overview. - Fire Safety Journal, 55, pp. 69-86.

Török A., P. Görög, Á. Török 2013: Hő hatására bekövetkező kőzetfizikai változások gránitos kőzetkörnyezetben. (Heat generated petrophysical changes in granitic rock masses). - In: Nagy, L., A. Takács (Eds): 3rd Kézdi Congress, Budapest University of Technology and Economics, Budapest, pp. 49-62. (in Hungarian) 